\title{
PENGARUH STRATEGI PENETAPAN HARGA TERHADAP LOYALITAS PELANGGAN PRODUK KILAT KHUSUS MITRA KORPORAT KANTOR POS PURWOKERTO
}

\author{
Martina Anggarwati H \\ Program Studi D-IV Logistik Bisnis Politeknik Pos Indonesia \\ Email: martinaanggarwati@gmail.com \\ Rosi Devi Yanti \\ Program Studi D-IV Logistik Bisnis Politeknik Pos Indonesia \\ Email: rosideviyanti82@gmail.com
}

DOI: http://dx.doi.org/10.35908/jeg.v5i1.916

\begin{abstract}
The pricing policy is thought to affect the level of customer loyalty in the Purwokerto Post Office delivery service. This research was conducted in order to determine customer ratings of price fixing determined by Purwokerto Post Office and determine the effect of pricing on customer loyalty. This research method uses descriptive quantitative method with a population size of 30 respondents, while the analysis uses simple linear regression analysis, data collection techniques are used to distribute questionnaires. The results showed that the customer's assessment of pricing is in the good category and pricing affects the customer loyalty of $83 \%$.
\end{abstract}

Keywords: Pricing Strategy, Customer Loyalty Kantor Pos Purwokerto

\section{ABSTRAK}

Kebijakan penetapan harga diduga mempengaruhi tingkat loyalitas pelanggan jasa pengiriman Kantor Pos Purwokerto. Penelitian ini dilaksanakan dalam rangka untuk mengetahui penilaian pelanggan terhadap penetapan harga yang ditetapkan Kantor Pos Purwokerto dan mengetahui pengaruh penetapan harga terhadap loyalitas pelanggan. Metode penelitian ini menggunakan metode kuantitatif yang secara deskriptif dengan ukuran populasi sebanyak 30 responden, sedangkan analisis menggunakan analisis regresi linier sederhana, teknik pengumpulan data digunakan untuk menyebarkan kuesioner. Hasil penelitian menunjukan bahwa penilaian pelanggan terhadap penetapan harga yaitu pada kategori baik dan penetapan harga berpengaruh dengan loyalitas pelanggan sebesar $83 \%$.

Kata Kunci : Pricing Strategy, Customer Loyalty Kantor Pos Purwokerto

\section{Pendahuluan}

1. Latar Belakang

Saat ini perkembangan industri jasa pengiriman mengalami peningkatan yang cukup pesat, membuka arus perdagangan barang atau jasa menjadi tidak terbatas kebutuhan akan jasa pengiriman semakin meningkat dan memenuhi kebutuhan masyarakat. Peningkatan tersebut mengakibatkan persaingan yang semakin ketat antar perusahaan yang bergerak dibidang yang sama sehingga perusahaan harus dapat menarik minat konsumen agar tertarik dengan jasa layanan pengiriman yang ditawarkan. PT Pos Indonesia adalah industri jasa pertama yang melakukan kerja sama dengan mitra yang disebut dengan pelanggan Korporat. Sistem korporat/korporasi adalah 
sistem transaksi kiriman yang bea kirimannya dihitung sebagai piutang dan ditagihkan di akhir bulan yang diberlakukan kepada mitra-mitra ber PKS (sudah melakukan perjanjian kerjasama). Sistem ini sifatnya kolektif dari satu pengirim mitra ditujukan kepada banyak penerima, bukan menggunakan sistem perorangan seperti loket. Kegiatan penetapan harga menjadi peranan penting dalam proses bauran pemasaran, karena penentuan harga terkait langsung nantinya dengan pendapatan yang diterima oleh perusahaan. Keputusan penentuan harga juga sedemikian penting dalam menentukan seberapa jauh layanan jasa dinilai oleh konsumen dan juga dalam proses membangun citra perusahaan. Penetapan harga produk layanan kiriman yang ditawarkan sebagian besar hal yang sangat penting dalam operasi perusahaan, terlebih lagi pada usaha yang berorientasi terhadap kepuasan pelanggan. Karena konsumen menggunakan suatu jasa dan menggunakan kembali suatu jasa tergantung dari persepsi konsumen tentang pelayanan yang didapat. Strategi penetapan harga sangat mempengaruhi karakteristik pengguna jasa itu sendiri, terlebih harga yang ditawarkan akan mempengaruhi keputusan pembelian konsumen tersebut.

Tabel 1 Penjualan Januari-April

\begin{tabular}{|c|c|c|c|}
\hline Bulan & Jenis Layanan & Jumlah Kiriman & Harga Kiriman \\
\hline Janiuari & Kilat Khusus & 9.841 & Rp. 130.223 .700 \\
\hline Februari & Kilat Khousus & 10.384 & Rp. $146.147,300$ \\
\hline Maret & Kilat Khusus & 10.115 & Rp. 117951900 \\
\hline April & Kilat Khurus & 215.982 & Rp. 171.289 .500 \\
\hline
\end{tabular}

Berdasarkan tabel diatas mengenai data kiriman untuk bulan Januari hingga April mengalami naik turun jumlah pengiriman di setiap bulan yang menggunakan layanan Kilat Khusus, ini membuktikan Kantor Pos Purwokerto belum berhasil membuat konsumen menjadi loyal menggunakan layanan yang diberikan. Meningkatkan loyalitas pelanggan dalam bidang pemasaran dapat dimulai dengan menganalisa perilaku pembelian dalam situasi yang tepat, sehingga dapat mempengaruhi pelanggan yang lain untuk menggunakan jasa yang ditawarkan.

Dalam loyalitas pelanggan menjadi satu hal yang penting untuk diperhatikan karena ini yang akan menjadi bahan pertimbangan dalam menentukan langkah-langkah strategi yang tepat. Namun loyalitas pelanggan dapat berubah-ubah dengan cepat sesuai dengan pengaruh yang berasal dari diri sendiri bahkan dari luar dirinya. sebab kebutuhan pengiriman merupakan cara efektif dan efisien dalam mengirimkan barang dengan tujuan domestik maupun internasional, maka tingkat harga menjadi pertimbangan bagi pelanggan untuk melakukan sikap menyampaikan kepada orang lain atau orang terdekat mengenai harga yang ditetapkan oleh perusahaan setelah itu adanya tindakan melakukan pembelian ulang dengan tujuan memenuhi kebutuhan pelangggan.

Dengan ini dari uraian diatas penelitian ini mengambil judul "Pengaruh Strategi Penetapan Harga Terhadap Loyalitas Pelanggan Produk Kilat Khusus Mitra Korporat Kantor Pos Purwokerto.

2. Rumusan Masalah

Berdasarkan latar belakang penelitian yang telah diuraikan, maka terdapat masalah dalam penelitian ini yaitu :

a. Bagaimana penilaian pelanggan terhadap penetapan harga pada pengiriman layanan Kilat Khusus yang ditetapkan oleh Kantor Pos Purwokerto?

b. Seberapa besar pengaruh penetapan harga terhadap loyalitas pelanggan korporat?

\section{Tujuan Penelitian}

Tujuan penelitian dari pelaksanaan penelitian ini adalah untuk mengetahui dan mengkaji :

a. Mengetahui penilaian pelanggan terhadap penetapan harga pada pengiriman layanan Kilat Khusus yang 


\section{ditetapkan oleh Kantor Pos Purwokerto?}

b. Menganalisis pengaruh penetapan harga terhadap loyalitas pelanggan korporat?

\section{Kegunaan Penelitian}

Dengan dilaksanakannya penelitian ini diharapkan dapat memberikan manfaat baik secara langsung maupun tidak langsung oleh berbagai pihak yang terlibat dalam kegiatan ini dan hasil penelitian diharapkan dapat berguna baik secara akademis maupun praktis dan mengetahui penilaian pelanggan terhadap jasa pengiriman paket pada penetapan harga yang diterapkan dan pelanggan menjadi loyal terhadap jasa layanan Kantor Pos Purwokerto.

\section{Tinjauan Pustaka}

5. Landasan Teori

a. Harga

Menurut Kotler \& Amstrong (2016:324) mendefinisikan bahwa : "Price the amount of money charged for a product or service, or the sum of the value that customers exchange for the benefits or having or using the product or service".(harga merupakan sejumlah uang yang dikeluarkan untuk sebuah produk atau jasa, atau sejumlah nilai yang ditukarkan oleh konsumen untuk memperoleh manfaat atau kepemilikan atau penggunaan atas sebuah produk atau jasa).

\section{b. Dimensi Harga}

Menurut Kotler dan Keller dalam Istiqomah (2018:3), menyatakan bahwa dimensi harga terdiri dari:

1.) Price List (Daftar harga)

2.) Discount (Rabat/Diskon)

3.) Allowance (Potongan harga khusus)

4.) Payment Period (Periode pembayaran)

c. Strategi Penetapan Harga

Menurut Kotler dan Armstrong yang dikutip kembali oleh Efendi (2015:132) ada 3 strategi dalam menetapkan harga :

1.) Market Skimming Pricing (Penetapan
Harga Market Skimming)

2.) Market Penetration Pricing (Penetapan Harga Penetrasi Pasar)

3.) Status Quo Pricing ( Penetapan Harga Status Quo)

d. Tujuan Penetapan Harga

Menurut Triputranto (2016:92) pada dasarnya ada tempat jenis tujuan penetapan harga, yaitu :

1.) Survival

2.) Profit Maximization

3.) Sales Maximization

4.) Prestige

5.) Berorientasi pada stabilitas harga

e. Faktor Penetapan Harga

Menurut Tjiptono yang dikutip kembali oleh Triputranto (2016:92) ada 2 faktor yang mempengaruhi penetapan harga, yaitu faktor internal yang berasal dari dalam perusahaan dan faktor eksternal yang berasal dari luar perusahaan.

Faktor-faktor Internal :

1.) Sasaran Pemasaran

2.) Strategi Bauran Pemasaran

3.) Struktur Biaya

4.) Pertimbangan Organisasi

Faktor-faktor Eksternal :

1.) Pasar dan Permintaan

2.) Persaingan

Faktor Eksternal lainnya

a.) Kondisi ekonomi

b.) Pedagang

c.) Pemerintah

f. Loyalitas Pelanggan

Menurut Fleming

(2016:34) menjelaskan loyalitas pelanggan adalah sikap dan keputusan pelanggan untuk tetap menggunakan suatu jasa tertentu.

Dimensi Loyalitas Pelanggan Menurut Griffin dalam Putra, F. Charisma dkk (2018:102) ciri-ciri pelanggan yang loyal 
terhadap perusahaan memiliki karakteristik sebagai berikut:

1.) Melakukan pembelian ulang secara teratur (Repeat Buying).

2.) Membeli antar lini produk dan jasa (Purcase Across).

3.) Mereferensikan kepada orang lain (Refers to Other).

4.) Menunjukkan kekebalan terhadap tarikan dari para pesaing (Immunity to other).

g. Ciri-ciri pelanggan Loyal Menurut Kotler yang dikutip kembali oleh Vinna (2015:238) menyatakan ciri-ciri konsumen yang Loyal sebagai berikut :

1.) Loyal terhadap produk

2.) Adanya komunikasi dari mulut ke mulut yang bersifat positif

3.) Perusahaan menjadi pertimbangan tertentu

h. Tingkatan Loyalitas

Menurut Oliver yang dikutip kembali oleh Vinna (2015:240) memiliki tingkatan loyalitas pelanggan terdiri atas empat tahap berikut :

1.) Loyalitas Kognitif

2.) Loyalitas Afektif

3.) Loyalitas Konatif

4.) Loyalitas Tindakan

\section{Hipotesis}

Berdasarkan uraian dan hasil penelitian yang dikembangkan oleh para ahli dan penelitian terdahulu di atas, maka hipotesis simultan yang diambil oleh penulis dari penelitian ini adalah perumusan hipotesis menunjukan bahwa adanya hubungan antara rumusan masalah penelitian, tujuan penelitian dan hipotesis penelitian mempunyai hubungan yang sangat erat, hipotesis yang diajukan dalam penelitian ini yaitu:

H0 : Terdapat penilaian pelanggan terhadap penetapan harga pada pengiriman paket layanan Kilat Khusus.

H1 : Terdapat pengaruh penetapan harga terhadap loyalitas pelanggan.

7. Kerangka Pemikiran

Gambar 1 Kerangka Pemikiran

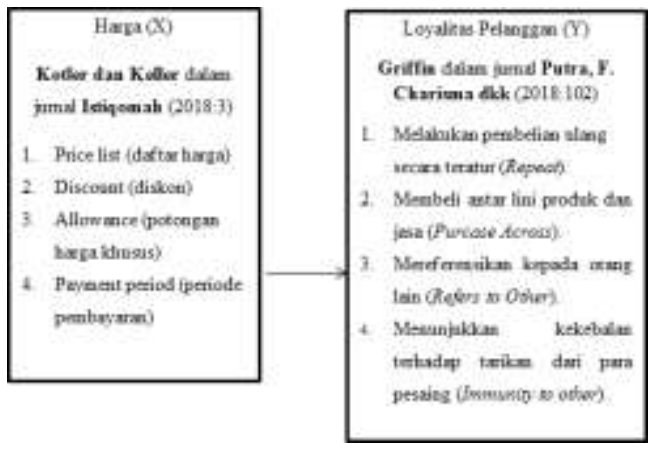

Sumber : diolah oleh Peneliti, 2019

\section{Metode Penelitian}

8. Rancangan (desain) Penelitian

Penelitian ini adalah penelitian yang menggunakan jenis Metode Kuantitatif dengan teknik pengumpulan data dengan menggunakan kuesioner.

9. Operasional Variabel

Operasional variabel digunakan sebagai petunjuk tentang bagaimana suatu variabel diukur dengan menggunakan indikator-insikator yang digunakan untuk mengukur variabel secara terperinci. Berdasarkan uraian bab II maka operasional variabel dalam penelitian ini adalah sebagai berikut:

a. Harga

Menurut Fandy Tjiptono (2016: 218) menyebutkan bahwa harga merupakan satusatunya unsur bauran pemasaran yang mendatangkan pemasukan atau pendapatan bagi perusahaan. Harga memiliki 4 dimensi menurut Kotler dan Keller dalam jurnal Istiqomah (2018:3) dengan menggunakan skala pengukuran likert, berikut dimensi dan indikator harga :

1.) Price List

Terdiri dari indikator keterjangkauan harga, Kesesuaian harga dengan manfaat, dan Kesesuaian harga dengan tingkat kemampuan daya beli.

2.) Discount

Terdiri dari indikator Memberian diskon pada tarif tertentu.

3.) Allowance

Terdiri dari indikator Memberikan Potongan harga khusus.

4.) Payment Period 
Terdiri dari indikator Memberikan jangka waktu pembayaran.

b. Loyalitas Pelanggan

Menurut Tjiptono (2014:392) loyalitas dalam konteks pemasaran jasa diartikan "sebagai respon yang terkait sangat erat dengan suatu perjanjian untuk memegang teguh komitmen yang mendasari kelangsungan relasi”. Loyalitas Pelanggan memiliki 4 dimensi menurut Griffin dalam jurnal Putra and Pangestuti (2018:102) dengan menggunakan skala pengukuran likert, berikut dimensi dan indikator Loyalitas Pelanggan.

1.) Repeat buying

Terdiri dari indikator Membeli ulang produk atau jasa dengan teratur/berkala, Membeli jasa layanan tambahan dan Melakukan pembelian paling sedikit $2 \mathrm{x}$ dalam selang waktu tertentu.

2.) Purcase Across

Terdiri dari indikator Membeli antar lini produk dan jasa pada perusahaan yang sama, Mencoba layanan baru yang ditawarkan Perusahaan, dan Percaya pada satu merek Kantor Pos Purwokerto.

\section{3.) Refers to Other}

Terdiri dari indikator Merekomendasikan keunggulan produk, Menyampaikan hal positif ke konsumen yang lain, dan Mengajak konsumen lain untuk menggunakan jasa layanan pos.

4.) Immunity to other

Terdiri dari indikator Memberikan feedback positif kepada Kantor Pos Purwokerto.

10. Populasi

Menurut Sugiyono (2017:136) populasi adalah keseluruhan element yang dijadikan wilayah generalisasi. Elemen populasi adalah keseluruhan subyek yang akan diukur, yang merupakan unit yang diteliti. Dalam hal ini populasi adalah wilayah generalisasi yang terdiri atas : obyek/subyek yang mempunyai kualitas dan karakteristik tertentu yang ditetapkan oleh peneliti untuk dipelajari dan kemudian di tarik kesimpulan. Jadi populasi bukan hanya orang, tetapi obyek dan benda-benda alam lainnya.

Dalam penelitian ini, populasi yang diteliti adalah mitra korporat yang menggunakan layanan kilat khusus yang diketahui memiliki 30 mitra korporat yang bekerja sama dengan Kantor Pos Purwokerto.

\section{Pengumpulan Data}

Adapun teknik pengumpulan data yang digunakan penelitian ini sebagai berikut:
a. Wawancara
b. Observasi
c. Kuesioner

\section{Metode Analisis Data}

a. Uji Validitas

Menurut Sugiono (2017:168) Biasanya syarat minimum untuk dianggap memenuhi syarat adalah kalau $\mathrm{r}=0,3$, jadi kalau korelasi antara butir dengan skor total kurang dari 0,3 maka butir dalam instrument tersebut dinyatakan tidak valid.

b. Uji Reliabilitas

Menurut Sugiyono (2017:199) "Instrumen yang reliabel adalah instrument yang bila digunakan beberapa kali untuk mengukur obyek yang sama, akan menghasilkan data yang sama. Pengukuran reliabilitas pada penelitian ini dilakukan denganmembagikan kuesioner pada responden kemudian hasil skor jawaban pertanyaan yang sama dengan menggunakan alat pengolaham data SPSS 23 menggunakan uji Cronbach Alpha . Suatu konstruk atau variabel dikatakan reliabel jika memberikan nilai Cronbach Alpha > 0,60.

c. Uji Normalitas

Menurut Sugiono (2017:235) penggunaan stastistik parametris bekerja dengan asumsi bahwa setiap data variabel penelitian yang akan dianalisis membentuk distribusi normal. Bila data dikatakan tidak normal, maka teknik stastistik parametris tidak dapat digunakan untuk alat analisis. Sebagai gantinya digunakan teknik stastistik 
ini adalah stastistik lain yang tidak harus berasumsi bahwa data berdistribusi normal. Maka uji normalitas ini dilakukan dengan menggunakan SPSS 23 yaitu uji normalitas Kolmogorov-smirnov. dari hasil statistic diperoleh hasil sebagai berikut

1.) Jika Signifikansi $>0.05$ maka distribusi dari populasi adalah normal.

2.) Jika Signifikansi < 0.05 maka populasi tidak berdistribusi secara normal.

a. Analisis Deskriptif

$$
\text { Menurut Sugiyono }
$$
berpendapat bahwa Analisis deskriptif adalah "Statistik yang digunakan untuk menganalisa data dengan cara mendeskripsikan atau menggambarkan data yang telah terkumpul sebagaimana adanya tanpa bermaksud membuat kesimpulan yang berlaku untuk umum atau generalisasi”. Berdasarkan presentase dengan cara dicari rata-ratanya dengan menggunakan rumus dari Husein Umar (2011:130) sebagai berikut :

$$
\text { Lebar skala }=\frac{b-1}{5}
$$

$$
=0,8
$$

\footnotetext{
Setelah rata-rata skor dihitung, makauntuk mengkategorikan mengklasifikasikan kecenderungan jawaban responden kedalam skala dengan formulasi sebagai berikut:

Skor minimum $=1$

Skor maksimum $=5$

Dengan demikian kategori skala dapat ditentukan sebagai berikut:
}

Tabel 2 Rentang Nilai

Sumber : Diolah oleh Peneliti, 2019

Berikut gambar garis kontinum untuk

\begin{tabular}{|cc|}
\hline Kentang Nilai & Kat egori \\
$1,00-1,80$ & Baik \\
$1,81-2,60$ & Baik \\
$2,61-3,40$ & Baik \\
$3,41-4,20$ & Baik \\
$4,21-5,00$ & Baik \\
\hline
\end{tabular}

melihat hasil dari kriteria intrepretasi nilai variable

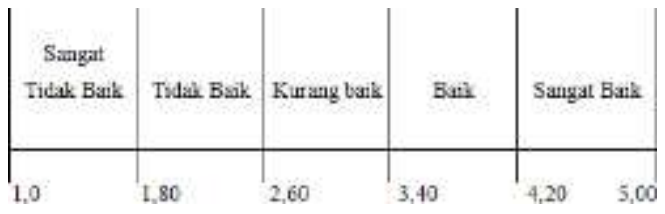

Gambar 2 Garis Kontinum

Sumber : Diolah oleh Peneliti, 2019

b. Analisis Regresi Linier Sederhana

Analisis regresi sederhana adalah sebuah metode pendekatan untuk permodelan hubungan antara satu variabel dependen dan satu variabel independen. Dalam model regresi, variabel independen menerangkan variabel dependenya. Dalam analisis regresi sederhana, hubungan antara variabel independen $(\mathrm{X})$ akan diikuti oleh perubahan pada variabel dependen (Y) secara tetap. Sementara hubungan non linier, perubahan variabel $\mathrm{X}$ tidak diikuti dengan perubahan variabel $\mathrm{Y}$ secara proposional. Penelitian ini untuk menganalisis pengaruh Strategi Penetapan Harga terhadap Loyalitas Pelanggan produk Kilat Khusus Mitra Korporat Kantor Pos Purwokerto dengan menggunakan rumus yang dikutip Sugiyono (2017:277) secara matematis model analisis regresi linier sederhana dapat digambarkan sebagai berikut

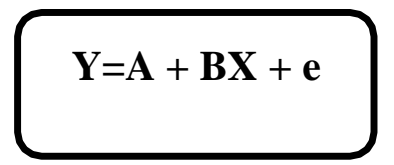

Keterangan

$\mathrm{Y}=\mathrm{variabel}$ dependen atau respon

$A=$ intercept atau konstanta

$\mathrm{B}=$ koefisien regresi atau slope

$\mathrm{e}=$ residual atau error

\section{c. Koefisien Determinasi}

Koefisien determinasi merupakan ukuran untuk mengetahui kesesuaian atau ketepatan antara nilai dugaan atau garis regresi dengan data sampel. Apabila nilai koefisien korelasi sudah diketahui maka untuk mendapatkan koefisien determinasi dapat diperoleh dengan mengkuadratkannya. Besarnya koefisen determinasi dapat dihitung dengan menggunakan rumus sebagai berikut: 


$$
\begin{aligned}
& K=r^{2} \times 100 \% \\
& \mathrm{KD}=\text { Koefisien Determinasi } \\
& \mathrm{r}^{2}=\text { Koefisien Korelasi }
\end{aligned}
$$

Kriteria untuk analisis koefisien determinasi adalah

1.) Jika $\mathrm{Kd}$ mendeteksi nol (0) maka pengaruh variabel independent terhadap variabel dependen lemah.

2.) Jika $\mathrm{Kd}$ mendeteksi satu (1), maka pengaruh independent terhadap variabel dependent kuat

\section{d. Uji Hipotesis 1.) Uji F}

Uji $F$ adalah pengujian terhadap koefisien regresi secara simultan. Pengujian ini dilakukan untuk mengetahui pengaruh semua variabel independen yang terdapat di dalam model secara bersama-sama (simultan) terhadap variabel dependen. Menurut Sugiyono (2018 : 192) uji f dirumuskan sebagai berikut:

$$
\mathrm{F}=\frac{\mathrm{R}^{2} / \mathrm{k}}{\left(1-\mathrm{R}^{2}\right) /(\mathrm{n}-\mathrm{k}-1)}
$$

Keterangan:

$\mathrm{R}^{2}=$ Koefisien determinasi

$\mathrm{K}=$ Jumlah variabel independen

$\mathrm{n}=$ Jumlah anggota data atau kasus

Uji $F$ hasil perhitungan ini dibandingkan dengan $\mathrm{F}_{\text {tabel }}$ yang diperoleh dengan menggunakan tingkatan resiko atau signifikan level 5\% atau

dengan degree freedom $=k$ (n-k-1) dengan kriteria sebagai berikut:

a.) $\mathrm{H}_{\mathrm{o}}$ diterima jika nilai $\mathrm{F}_{\text {hitung }} \leq \mathrm{F}_{\text {tabel }}$ atau nilai sig $>\alpha$

b.) $\mathrm{H}_{\mathrm{o}}$ diterima jika nilai $\mathrm{F}_{\text {hitung }} \geq \mathrm{F}_{\text {tabel }}$ atau nilai sig $<\alpha$

Jika terjadi penerimaan $\mathrm{H}_{0}$, maka dapat diartikan tidak berpengaruh signifikan model regresi berganda yang diperoleh sehingga mengakibatkan tidak signifikan pula pengaruh dari variabel- variabel bebas bebas secara simultan terhadap variabel terikat.

\section{Hasil Penelitian}

13. Hasil penelitian

a. Uji Validitas

Tabel 3 Uji Validitas Variabel X

Item-Total Statistics

\begin{tabular}{|ccccc|}
\hline & $\begin{array}{c}\text { Scale Mean if } \\
\text { Item Deleted }\end{array}$ & $\begin{array}{c}\text { Scale } \\
\text { Item Deleted }\end{array}$ & $\begin{array}{c}\text { Corrected } \\
\text { Item-Total } \\
\text { Correlation }\end{array}$ & $\begin{array}{c}\text { Cronbach's } \\
\text { Alpha if Item } \\
\text { Deleted }\end{array}$ \\
\hline x1.1 & 20.2667 & 7.651 & .600 & .844 \\
x1.2 & 20.0333 & 8.447 & .648 & 1827 \\
x1.3 & 19.9333 & 8.064 & .755 & .808 \\
x2.1 & 20.0667 & 8.961 & .531 & .848 \\
x3.1 & 20.1333 & 7.913 & .700 & .817 \\
x4.1 & 20.2333 & 8.875 & .661 & .828 \\
\hline
\end{tabular}

Sumber : Diolah Oleh aplikasi SPSS 23

Tabel 4 Uji Validitas Variabel Y

Sumber : Diolah Oleh aplikasi SPSS 23

Dari tabel diatas, hasil uji validitas pada variabel (X) Harga dan variabel (Y) Loyalitas Pelanggan, diketahui bahwa semua item skor dari setiap instrumen adalah $r$ hitung $>r$ tabel

Item-Total Statistics

\begin{tabular}{|lrrrr|}
\hline & $\begin{array}{c}\text { Scale Mean if } \\
\text { Item Deleted }\end{array}$ & $\begin{array}{c}\text { Seale } \\
\text { Variance if }\end{array}$ & $\begin{array}{c}\text { Corrected } \\
\text { Item-Total } \\
\text { Correlation }\end{array}$ & $\begin{array}{c}\text { Cronbach's } \\
\text { Alpha ir Item } \\
\text { Deleted }\end{array}$ \\
\hline y1.1 & 55.6333 & 43.964 & .718 & .744 \\
y1.2 & 35.4000 & 15.760 & .839 & .860 \\
y1.3 & 55.5000 & 44.052 & .097 & .745 \\
y2.1 & 55.6000 & 46.524 & .468 & .762 \\
y2.2 & 55.8667 & 43.292 & .586 & .745 \\
y2.3 & 55.6667 & 44.851 & .646 & .750 \\
y3.1 & 55.6000 & 45.903 & .439 & .761 \\
y3.2 & 55.5333 & 43.775 & .097 & .743 \\
y3.3 & 55.4333 & 40.737 & .480 & .763 \\
y4.1 & 55.5667 & 41.357 & .831 & .726 \\
\hline
\end{tabular}

dengan signifikan 0,3, maka dapat disimpulkan bahwa semua pernyataan dari variabel $\mathrm{X}$ dan $\mathrm{Y}$ dinyatakan valid dan dapat digunakan dalam pengujian selanjutnya.

b. Uji Reliabilitas

Tabel 5 Uji Reliabilitas Variabel X 
Reliability Statistics

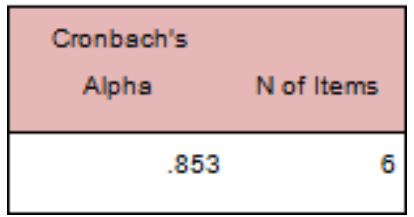

Sumber : Diolah Oleh aplikasi SPSS 23

Dari hasil pengolahan data dapat dilihat pada tabel di atas bahwa nilai Crombach's Alpha 0,853 > 0,6. Maka item pernyataan pada variabel Harga sebagai $X$ adalah reliabel.

\section{Tabel 6 Uji Reliabilitas Variabel Y Reliability Statistics}

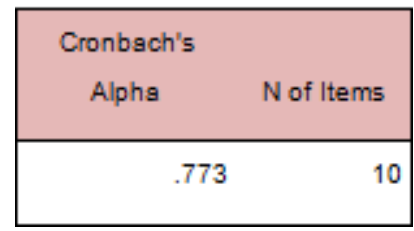

Sumber : Diolah Oleh aplikasi SPSS 23

Dari hasil pengolahan data dapat dilihat pada tabel di atas bahwa nilai Crombach's Alpha 0,773 > 0,6. Maka item pernyataan pada variabel Loyalitas Pelanggan sebagai Y adalah reliabel.

c. Uji Normalitas

Tabel 7 Uji Normalitas

One-Sample Kolmogorov-Smirnov Test

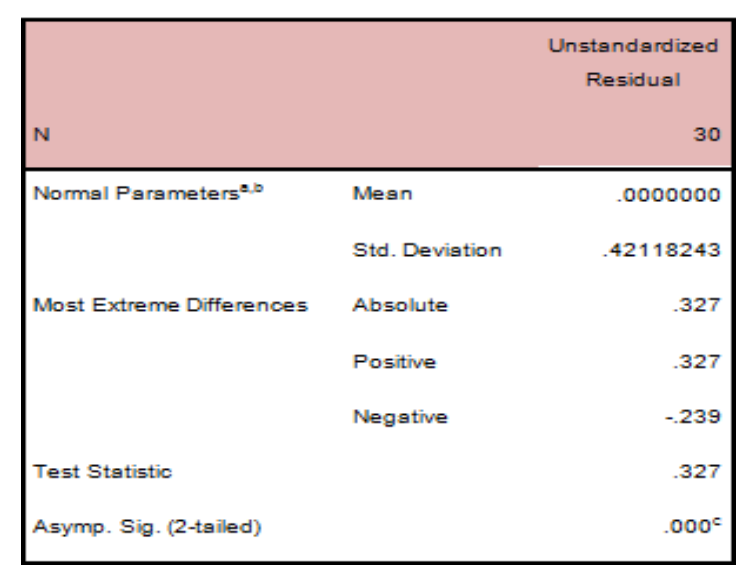

Sumber : Diolah Oleh aplikasi SPSS 23

Berdasarkan table diatas, diketahui bahwa nilai sighnifikansi sebesar 0,327. Jika nilai signifikasi $>0,005$ maka data tersebut berdistribusi normal. Dengan demikian, nilai signifikasi $0,327>0,005$ maka dapat disimpulkan bahwa data yang diuji berdistribusi normal.

\section{d. Analisis Deskriptif}

Dalam penelitian responden yang dianalisis adalah mitra korporat yang bekerja sama dengan Kantor Pos Purwokerto. Berdasarkan data responden yang berjumlah 30, berdasarkan nama, nama perusahaan, jabatan perusahaan.

Tabel 8 Rekapitulasi Penilaian Pelanggan Variabel X

\begin{tabular}{|lllll|}
\hline No. & Dimensi & Skor Aktual & Skor rata-rata & kategeri \\
\hline 1. & Price List & 357 & 4,1 & Baik \\
2. & Discount & 122 & 4,1 & Baik \\
3. & Allowance & 120 & 4,0 & Baik \\
4. Payment Period & 117 & 3,9 & Baik \\
\multicolumn{2}{l}{ TOTAL } & & 4,0 & Baik \\
\hline
\end{tabular}

Sumber : Diolah Oleh Peneliti, 2019

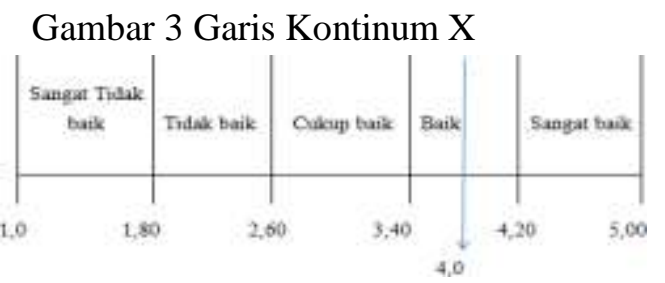

Sumber : Diolah Oleh Peneliti, 2019

Berdasarkan tabel diatas pada variabel penetapan harga dapat disimpulkan bahwa besarnya rata-rata skor total 4,0 berada dikategori baik, jadi berdasarkan analisis dan uji diatas maka dapat menjawab pertanyaan pada rumusan masalah bagaimana penilaian pelanggan terhadap penetapan harga yang ditetapkan Kantor Pos Purwokerto.

e. Analisis Regresi Sederhana

Tabel 9 Analisis Regresi Sederhana

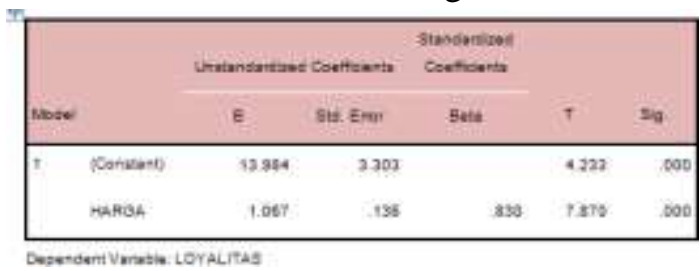

Sumber : Diolah Oleh aplikasi SPSS 23

Pada Tabel Hasil Uji Regresi Linier terdapat kolom B yang merupakan nilai constant (a) adalah 13,984 sedangkan trust (b) adalah 1,067 sehingga mendapatkan persamaan regresi linier sederhana sebagai berikut :

$$
\begin{aligned}
& \mathrm{Y}=\mathrm{a}+\mathrm{Bx} \\
& \mathrm{Y}=13,984+1,067
\end{aligned}
$$

Dimana $X$ merupakan Penetapan Harga 
dan Y merupaka Loyalitas Pelanggan. Koefisien b dinamakan koefisien arah regresi dan menyatan perubahan rata-rat variabel Penetapan Harga (X) dan merupaka Loyalitas Pelanggan (Y) untuk setiap perubahan variabel $X$ sebesar satu-satuan.

Perubahan tersebut merupakan penambahan bila $b$ bertanda positif dan penurunan bila $b$ bertanda negatif. Sehingga dari persamaan tersebut dapat diterjemahkan sebagai berikut :

1.) Konstan sebesar 13,984 menyatakan bahwa jika kemampuan penetapan harga adalah 0 maka loyalitas pelanggan akan mencapai penjualan sebesar 13,984

2.) Koefisien regresi $X$ sebesar 1,067 menyatakan bahwa jika kemampuan penetapan harga mengalami peningkatan maka loyalitas pelanggan akan meningkat sebesar 1,067 atau 10,67\%. Koefisisen bernilai positif, artinya terjadi hubungan positif antar penetapan harga dengan peningkatan loyalitas pelanggan, semakin meningkat kemampuan penetapan harga maka semakin meningkat penjualan yang dicapai.

\section{f. Koefisien Determinasi}

Tabel 10 Koefisien Determinasi Model Summary ${ }^{\circ}$

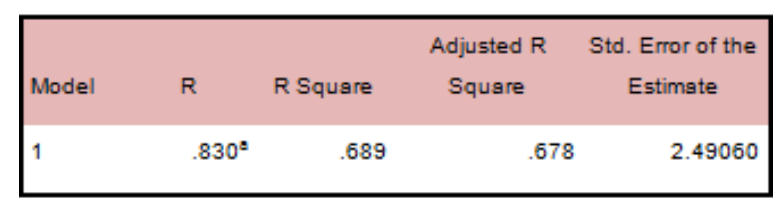

๑. Predictors: (Constant), HARGA

b. Dependent Variable: LOYALITAS

Sumber : Diolah Oleh aplikasi SPSS 23

Berdasarkan angka $\mathrm{R}$ sebesar 0,830 dapat ditarik untuk digunakan sebagai besarnya pengaruh penetapan harga terhadap loyalitas pelanggan. Koefisien determinasi menggunakan rumus sebagai berikut:

$$
\begin{aligned}
& \mathrm{KD}=\mathrm{r}^{2} \times 100 \% \\
& \mathrm{KD}=0.830 \times 100 \% \\
& \mathrm{KD}=83 \%
\end{aligned}
$$

$$
\text { Dapat diartikan bahwa pengaruh }
$$

penetapan harga terhadap loyalitas pelanggan sebesar $83 \%$ sedangkan $17 \%$ dipengaruh oleh faktor lain.

\begin{tabular}{|c|c|c|c|c|c|c|}
\hline \multicolumn{2}{|c|}{ Model } & \multirow{2}{*}{$\begin{array}{c}\begin{array}{c}\text { Sum of } \\
\text { Squares }\end{array} \\
384.180\end{array}$} & \multirow{2}{*}{$\frac{\text { df }}{1}$} & Mesn Square & \multirow{2}{*}{$\frac{F}{61.934}$} & \multirow{2}{*}{$\frac{\text { Sig. }}{.000^{\circ}}$} \\
\hline 1 & Regression & & & 384.180 & & \\
\hline & Residual & 173.686 & 28 & 6.203 & & \\
\hline & Total & 557.867 & 29 & & & \\
\hline
\end{tabular}

g. Uji F

Tabel 11 Uji F

ANOVA:

9. Dependent Variable: LOYALITAS

b. Predictors: (Constant), HARGA

Sumber : Diolah Oleh aplikasi SPSS 23

1.) Jika $\mathrm{f}$ hitung $>\mathrm{f}$ tabel maka $\mathrm{HO}$ ditolak dan Ha diterima (berpengaruh)

2.) Jika f hitung $<\mathrm{f}$ tabel maka $\mathrm{HO}$ diterima dan Ha ditolak (tidak berpengaruh)

Dari tabel diatas dapat diketahui $\mathrm{f}$ hitung $=61,934$ dan $\mathrm{f}$ tabel $=4,20$ maka penetapan harga berpengaruh dengan loyalitas pelanggan. Dilihat dari $\mathrm{f}$ hitung $=61,934>\mathrm{f}$ tabel $=4,20$ maka menunjukan bahwa penetapan harga berpengaruh terhadap loyalitas pelanggan secara simultan, maka $\mathrm{H} 0$ ditolak $\mathrm{H} 1$ diterima memiliki arti bahwa ada pengaruh signifikan antara variabel penetapan harga $(\mathrm{X})$ dengan loyalitas pelanggan $(\mathrm{Y})$.

\section{Kesimpulan Dan Saran}

1. Kesimpulan

a. Berdasarkan Penelitian Penilaian Pelanggan terhadap Penetapan Harga dinyatakan Baik maka konsumen ada kemungkinan untuk melakukan pembelian ulang, jika penilaian pelanggan sangat tidak baik maka konsumen akan merasa kecewa dan bahkan tidak melakukan pembelian ulang. Oleh karena itu perusahaan harus memperhatikan aspek-aspek yang ada agar konsumen merasa puas.

b. berdasarkan hasil Koefisien Determinasi dan Uji F diketahui bahwa Penetapan Harga berpengaruh secara simultan terhadap Loyalitas Pelanggan.

2. Saran 
a. Untuk meningkatkan konsumen menggunakan kembali produk perusahaan maka perusahaan harus mempertimbangkan harga sesuai dengan tingkat daya beli konsumen.

b. Perusahaan juga harus memperhatikan kesesuaian harga dengan tingkat loyalitas pelanggan yang dirasakan oleh konsumen. Karena tingkat kepuasan konsumen akan mempengaruhi pembelian ulang sehingga konsumen yang merasa puas dapat merekomendasikan hal itu kepada pelanggan lain agar mereka juga menggunakan atau tetap setia menggunakan layanan Kantor Pos Purwokerto.

\section{DAFTAR PUSTAKA}

Batubara, Azmiani dan Hidayat. 2016. Pengaruh penetapan harga dan promosi terhadap tingkat penjualan tiket pada Psa Mihin Lanka airlines. Jurnal ilman, Vol.4, No. 1, pp. 3346, Feb 2016.

Saragih, Henri. 2015. Analisis strategi penetapan harga dan pengaruhnya terhadap volume penjualan. Jurnal ilmah methonomi Vol.1, No.2, (Julidesember 2015) 2016.

Oktavian, F Rizky. 2018. Pengaruh Kualitas Pelayanan dan penetapan harga terhadap kepuasan pelanggan serta dampaknya pada loyalitas pelanggan (penelitian pada BNI Card Center LNC jakarta). Jurnal manajemen dan bisnis (almana) vol. 2 no. 2 /agustus 2018

Shartykarini, Shary dkk. 2016. Pengaruh Harga, kualitas produk dan kualitas layanan terhadap kualitas layanan terhadap kepuasan pelanggan dalam membentuk loyalitas pelanggan (studi pengunjung cafe di banjarbaru). Jurnal Wawasan Manajemen, Vol. 4, Nomor 1, Februari 2016.

Istiqomah, Kurnia. 2018. Strategi Penetapan Harga Tiket Kereta Api
Argo Parahyangan Sewaktu Terhadap Keputusan Pembelian Survey Terhadap Pengguna Jasa Kereta Api Argo Parahyangan Di Stasiun Bandung.

Putra, F. Charisma dkk. 2018. PENGARUH KUALITAS PELAYANAN TERHADAP KEPUASAN DAN LOYALITAS PELANGGAN (Survei pada Pelanggan Bengkel AUTO 2000 Sukun Malang). Jurnal Administrasi Bisnis (JAB)|Vol. 61 No. 2 Agustus 2018

Suwarni, Mayasari D. 2011. Pengaruh kualitas produk dan harga terhadap loyalitas pelanggan. Jurnal Ekonomi Bisnis TH.16, No.1, Maret 2011

Julvitra, Enos. 2015. Pengaruh penetapan harga dan kualitas pelayanan terhadap kepuasan pelanggan serta implikasinya terhadap loyalitas pelanggan pada topas galeria hotel bandung.

Kurniasih, d. 2012. Pengaruh harga dan kualitas pelayanan terhadap loyalitas pelanggan melalui variabel kepuasan (studi pada bengkel ahas). Jurnal Administrasi Bisnis Volume I Nomor 1 September 2012.

Triputranto. 2016. Manajemen Pemasaran. Indonesia : Politeknik Pos Indonesia. Bandung

Setiyaningrum, 2015. Prinsip-prinsip Pemasaran : Andi Yogyakarta

Sugiyono, 2018. Metode Penelitian Kuantitatif. Indonesia: Afabeta Bandung

Sugiyono, 2017. Metode Penelitian Bisnis. Indonesia: Afabeta Bandung 